\title{
A New Decavanadate with Organic Cation: Synthesis, Crystal Structure, and Hirshfeld Surface Analysis
}

\author{
Rawia Nasri $\left(\mathbb{D},{ }^{1}\right.$ Regaya Ksiksi, ${ }^{1,2}$ Mohsen Graia, ${ }^{3}$ and Mohamed Faouzi Zid ${ }^{1}$ \\ ${ }^{1}$ University of Tunis El Manar, Faculty of Sciences of Tunis, Laboratory of Materials, \\ Crystal Chemistry and Applied Thermodynamics, 2092 El Manar II, Tunis, Tunisia \\ ${ }^{2}$ University of Carthage, High Institute of Preparatory Studies in Biology and Geology (ISEP-BG) of Soukra, Soukra, Tunisia \\ ${ }^{3}$ Faculty of Sciences of Sfax, Solid State Laboratory, Faculty of Sciences, University of Sfax, 1171 Sfax 3000, Tunisia \\ Correspondence should be addressed to Rawia Nasri; rawia_nasri86@yahoo.com
}

Received 24 February 2021; Accepted 18 July 2021; Published 28 July 2021

Academic Editor: Jun Liu

Copyright () 2021 Rawia Nasri et al. This is an open access article distributed under the Creative Commons Attribution License, which permits unrestricted use, distribution, and reproduction in any medium, provided the original work is properly cited.

\begin{abstract}
A new 2,6-bis aminomethyl piperidine decavanadate hydrate, $\left(\mathrm{C}_{7} \mathrm{~N}_{3} \mathrm{H}_{20}\right)_{2} \mathrm{~V}_{10} \mathrm{O}_{28} \cdot 4 \cdot 21 \mathrm{H}_{2} \mathrm{O}$, was synthesized by slow evaporation of a solution at room temperature. The molecular structure was investigated by single-crystal X-ray diffraction. In the crystal structure, the layers of decavanadate groups, organic cations, and water molecules are arranged parallel to the (010) plane. Also, the prepared compound has been analysed by FTIR spectroscopy and scanning electron microscopy (SEM). The crystal structure of the title compound is stabilized by hydrogen bonds and van der Waals interactions. The cohesion of the structure is ensured by $\mathrm{O}-\mathrm{H}$... O and N-H. . O hydrogen bonds. The three-dimensional Hirshfeld surface (3D-HS) and the relative two-dimensional fingerprint plots (2D-FPs) of $\left(\mathrm{C}_{7} \mathrm{~N}_{3} \mathrm{H}_{20}\right)_{2} \mathrm{~V}_{10} \mathrm{O}_{28} \cdot 4.21 \mathrm{H}_{2} \mathrm{O}$ compound revealed that the structure is dominated by $\mathrm{O} \ldots \mathrm{H} / \mathrm{H} \ldots \mathrm{O}$ (70.8\%) and $\mathrm{H}$...H (18.5\%) contacts.
\end{abstract}

\section{Introduction}

Recently, the influence of noncovalent interactions has been widely studied due to their importance for the selfassembly and supramolecular stabilization [1]. However, hydrogen bonding has a significant function in crystal structure construction because of highly directive and relatively strong specific interactions [2]. These interactions exist in polyoxometalate (POM) groups, and the cohesion of these compounds is ensured by hydrogen bonds and van der Waals interactions, which encourage researchers to study this family especially in the field of biology [3]. Polyoxometalates (POMs) are a kind of inorganic clusters, which can be combined with organic ligands and metal ions to form supramolecular compounds. These groups have been extensively studied due to their potential applications in various fields such as catalysis [4], materials science [5], and antibacterial and antitumor activities [6]. Among the various types of
POMs, polyoxovanadates (POVs) are an important part of the group and invariably contain highly symmetrical core assemblies of $\mathrm{VO}_{n}$ units, which assemble into either discrete molecular clusters or link together to form onedimensional chains, two-dimensional layers, or threedimensional frameworks [7]. Several previous studies have shown that the decavanadate group has a significant role in some biological reactions $[8,9]$. This role is derived mainly from interactions between anions and biological molecules such as proteins $[10,11]$. These molecules have a nanomolar affinity for casein kinase 2 (CK2), making them the most potent inhibitors of CK2 to date [12]. Decavanadate compounds are known for their low toxicity and very potent antitumor activities. These results are verified by several authors such as Aissa et al. [13], Liu et al. [7], and Louati et al. [14].

In this paper, we report the synthesis, crystal structure, and Hirshfeld surface analysis of the novel decavanadate $\left(\mathrm{C}_{7} \mathrm{~N}_{3} \mathrm{H}_{20}\right)_{2} \mathrm{~V}_{10} \mathrm{O}_{28} \cdot 4.21 \mathrm{H}_{2} \mathrm{O}$. 
TABLE 1: Crystallographic characteristics, X-ray data collection, and structure-refinement parameters for $\left(\mathrm{C}_{7} \mathrm{~N}_{3} \mathrm{H}_{20}\right)_{2} \mathrm{~V}_{10} \mathrm{O}_{28} \cdot 4.21 \mathrm{H}_{2} \mathrm{O}$.

\begin{tabular}{|c|c|}
\hline System, sp. gr., $Z$ & Monoclinic, $\mathrm{P} 2_{1} / c, 2$ \\
\hline$a, b, c(\AA)$ & $10.488(3), 15.441(2), 25.841(6)$ \\
\hline$\beta\left({ }^{\circ}\right)$ & $90.14(2)$ \\
\hline$V\left(\AA^{3}\right)$ & $4184.98(1)$ \\
\hline$\rho_{\text {calc }}\left(\mathrm{g} \mathrm{cm}^{-3}\right)$ & 2.08 \\
\hline Radiation, $\lambda(\AA)$ & $\mathrm{MoK}_{\alpha}, 0.71073$ \\
\hline$\mu\left(\mathrm{mm}^{-1}\right)$ & 2.219 \\
\hline$T(\mathrm{~K})$ & 298 \\
\hline Sample size $\left(\mathrm{mm}^{3}\right)$ & $0.25 \times 0.19 \times 0.15$ \\
\hline Scan mode & $\omega / 2 \theta$ \\
\hline Absorption correction & Psi-scan \\
\hline$T_{\min }, T_{\max }$ & $0.9052,0.9996$ \\
\hline$\theta_{\max }\left({ }^{\circ}\right)$ & 22.00 \\
\hline$h, k, l$ ranges & $0 \leq h \leq 11,0 \leq k \leq 16,-27 \leq l \leq 27$ \\
\hline Number of reflections: measured/unique (N1) & $5454 / 5113(N 1)$ \\
\hline$R_{\text {int }}$ & 0.05 \\
\hline Number of refined parameters & 616 \\
\hline$R\left(F^{2}\right) / \mathrm{wR}\left(F^{2}\right) /$ relative to $\mathrm{N} 1$ & $0.091 / 0.222$ \\
\hline Number of reflections $(I>2 \sigma(I)(N 2))$ & $3881(N 2)$ \\
\hline$R\left(F^{2}\right) / / \mathrm{wR}\left(F^{2}\right)$ relative to $\mathrm{N} 2$ & $0.074 / 0.207$ \\
\hline$S$ & 1.074 \\
\hline$\Delta \rho_{\max } / \Delta \rho_{\min }, \mathrm{e} / \AA^{3}$ & $1.63 /-0.94$ \\
\hline
\end{tabular}

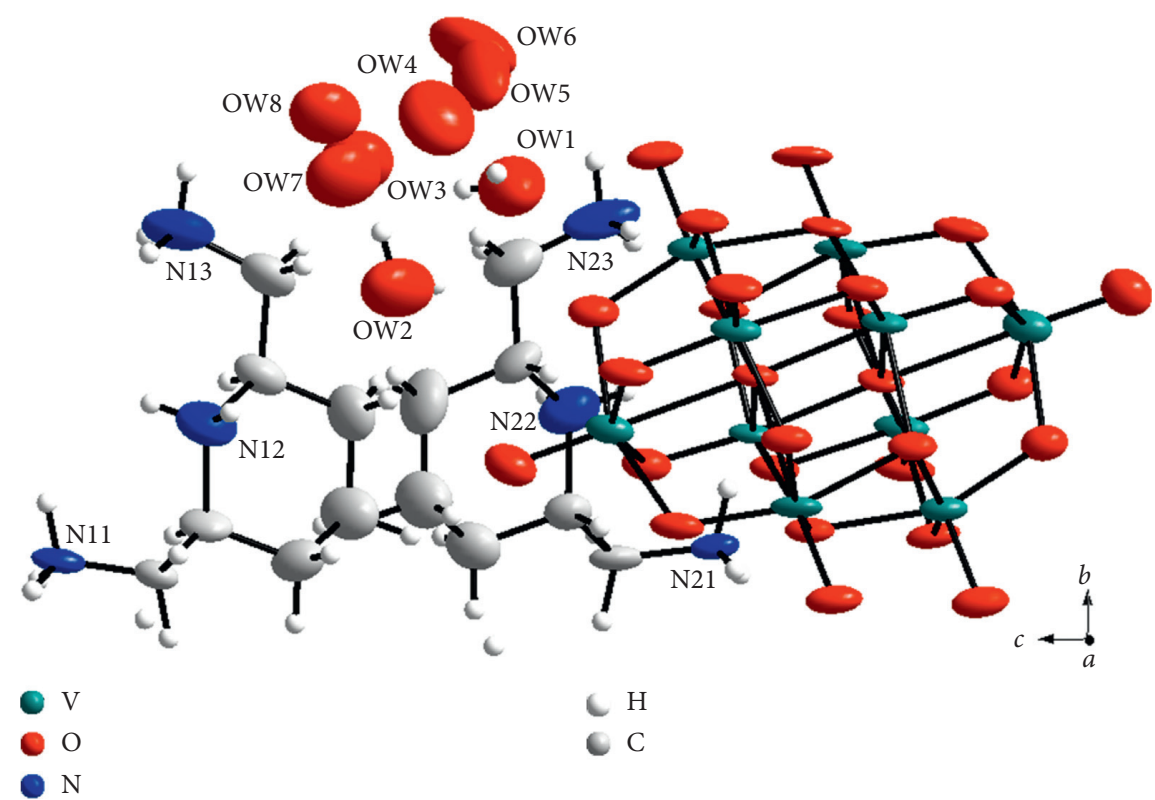

Figure 1: A view of the formula unit of $\left(\mathrm{C}_{7} \mathrm{~N}_{3} \mathrm{H}_{20}\right)_{2} \mathrm{~V}_{10} \mathrm{O}_{28} \cdot 4.21 \mathrm{H}_{2} \mathrm{O}$. Displacement ellipsoids are drawn at the $50 \%$ probability level.

\section{Experimental}

2.1. Materials and Physical Measurements. The infrared spectrum was measured at room temperature, using a Perkin Elmer Spectrum $^{\mathrm{TM}} 100$ FTIR spectrometer (France, Perkin Elmer) in the $4000-500 \mathrm{~cm}^{-1}$ region, in an ATR cell.

The SEM-EDX (energy dispersive X-ray) was made of a single crystal chosen by a polarizing microscope. Scanning electron microscopy (SEM) coupled to energy dispersive X-ray analysis spectrometry is performed using an FEI Quanta 200 environmental apparatus (LEUVEN Belgium, PHILIPS/FEI).
2.2. Synthesis of 2,6-Bis Aminomethyl Piperidinium Decavanadate Hydrate $\left(\mathrm{C}_{7} \mathrm{~N}_{3} \mathrm{H}_{20}\right)_{2} \mathrm{~V}_{10} \mathrm{O}_{28} 4.21 \mathrm{H}_{2} \mathrm{O}$. The crystals are obtained from a mixture of vanadium oxide $\left(\mathrm{V}_{2} \mathrm{O}_{5}\right)$ (Fluka, 99.9\%) and 2,6-bis (ammoniomethyl) piperidinium (Sigma-Aldrich, 96\%) in water with the respective molar proportion of $1: 4$. The mixture obtained is stirred with magnetic stirring, along with heating for about 3 hours. The solution thus obtained is transferred to a Petri dish. After a few days, the solution allows to deposit orange-coloured crystals suitable for X-ray diffraction analysis. 


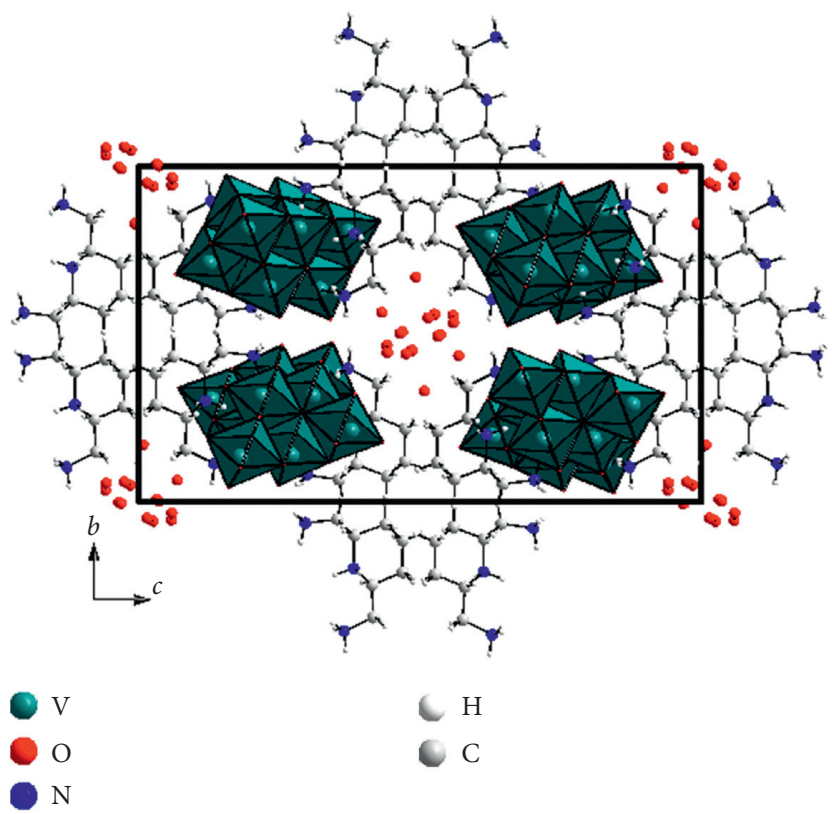

Figure 2: Projection of the $\left(\mathrm{C}_{7} \mathrm{~N}_{3} \mathrm{H}_{20}\right)_{2} \mathrm{~V}_{10} \mathrm{O}_{28} \cdot 4.21 \mathrm{H}_{2} \mathrm{O}$ structure along the [100] direction.

TABLE 2: Distortion, indexes (ID), and BVS calculations for $\left(\mathrm{C}_{7} \mathrm{~N}_{3} \mathrm{H}_{20}\right)_{2} \mathrm{~V}_{10} \mathrm{O}_{28} \cdot 4.21 \mathrm{H}_{2} \mathrm{O}$.

\begin{tabular}{|c|c|c|c|c|c|}
\hline Octahedra & ${\mathrm{V} 1 \mathrm{O}_{6}}$ & ${\mathrm{~V} 2 \mathrm{O}_{6}}$ & $\mathrm{~V}_{3} \mathrm{O}_{6}$ & $\mathrm{~V}_{4} \mathrm{O}_{6}$ & $\mathrm{~V}_{5} \mathrm{O}_{6}$ \\
\hline BVS & 4.955 & 4.925 & 4.978 & 5.000 & 4.889 \\
\hline ID & 0.081 & 0.083 & 0.086 & 0.0813 & 0.0814 \\
\hline Octahedra & $\mathrm{V} \mathrm{O}_{6}$ & $\mathrm{~V} \mathrm{O}_{6}$ & $\mathrm{~V} 8 \mathrm{O}_{6}$ & $\mathrm{~V} \mathrm{O}_{6}$ & $\mathrm{~V}_{10 \mathrm{O}_{6}}$ \\
\hline BVS & 4.910 & 4.934 & 5.000 & 5.051 & 4.986 \\
\hline ID & 0.099 & 0.100 & 0.167 & 0.088 & 0.009 \\
\hline
\end{tabular}

2.3. X-Ray Diffraction Study. A single orange crystal of $\left(\mathrm{C}_{7} \mathrm{~N}_{3} \mathrm{H}_{20}\right)_{2} \mathrm{~V}_{10} \mathrm{O}_{28} \cdot 4.21 \mathrm{H}_{2} \mathrm{O}$ was selected and used for $\mathrm{X}$-ray diffraction experiment. Intensity data were collected using an Enraf-Nonius CAD-4 automatic diffractometer equipped with graphite monochromatic $\operatorname{MoK} \alpha(\lambda=0.7107 \AA)$. The data reduction was processed with XCAD4 [15] included in the WINGX software package [16]. The structure was solved by the direct method using the program SHELXL-97 [17] and refined against $F^{2}$ data using the program SHELXL-2014 [18]. The reflections were corrected for Lorentz and polarization effects followed by psi-scan absorption correction [19]. All nonhydrogen atoms were refined with anisotropic atomic displacement parameters, whereas all hydrogen atoms were fixed using the HFIX instruction. The structure representation was prepared using DIAMOND [20]. The crystal data of $\left(\mathrm{C}_{7} \mathrm{~N}_{3} \mathrm{H}_{20}\right)_{2} \mathrm{~V}_{10} \mathrm{O}_{28} \cdot 4.21 \mathrm{H}_{2} \mathrm{O}$ are summarized in Table 1 . The CIF file containing complete information about the structure of the obtained structure was deposited in the Cambridge Crystallographic Data Center (CCDC no. 1968413); the file is freely available upon request to the following website: http:// www.ccdc.cam.ac.uk/data_request/cif.

2.4. Hirshfeld Surface Study. The molecular Hirshfeld surface is created based on the electron distribution of a molecule and has been calculated as the sum of electron densities of spherical atoms. The Hirshfeld surface was produced from the asymmetric unit of the $\left(\mathrm{C}_{7} \mathrm{~N}_{3} \mathrm{H}_{20}\right)_{2} \mathrm{~V}_{10} \mathrm{O}_{28} \cdot 4.21 \mathrm{H}_{2} \mathrm{O}$ molecule. The Hirshfeld surfaces are mapped with $d_{\text {norm }}$, and $2 \mathrm{D}$ fingerprint plots presented in this paper were generated using Crystal Explorer 3.1 [21]. The mapping of $d_{\text {norm }}$ on the Hirshfeld surface highlights the directional intermolecular interactions. The value of the $d_{\text {norm }}$ is negative or positive when intermolecular contacts are shorter or longer than van der Waals separations.

\section{Results and Discussion}

3.1. Crystal Structure. The single-crystal X-ray diffraction analysis shows that the formula unit of $\left(\mathrm{C}_{7} \mathrm{~N}_{3} \mathrm{H}_{20}\right)_{2} \mathrm{~V}_{10} \mathrm{O}_{28} \cdot 4.21 \mathrm{H}_{2} \mathrm{O}$ consists of one $\left[\mathrm{V}_{10} \mathrm{O}_{28}\right]^{6-}$ decavanadate group, two organic cations of 2,6-bis (ammoniomethyl) piperidinium, and 4.21 water molecules (Figure 1). The $\left[\mathrm{V}_{10} \mathrm{O}_{28}\right]^{6-}$ anions consist of ten sharing edges $\left[\mathrm{VO}_{6}\right]$ which is similar to those reported in the literature [22]. The decavanadate group in this structure is noncentrosymmetric. The $\mathrm{V}-\mathrm{O}$ distances in this group depend on the type of oxygen atoms involved: they are between 1.575(4) and 1.620(4) $\AA$ for terminal oxygen atoms, between 1.680(4) and 2.080(4) $\AA$ for doubly coordinated oxygen atoms, between 1.923(4) and 2.046(3) $\AA$ for triply coordinated oxygen atoms, and between 2.090(3) $\AA$ and 2.355(4) $\AA$ for hexacoordinated oxygen atoms. $\mathrm{V}-\mathrm{V}$ distances range 


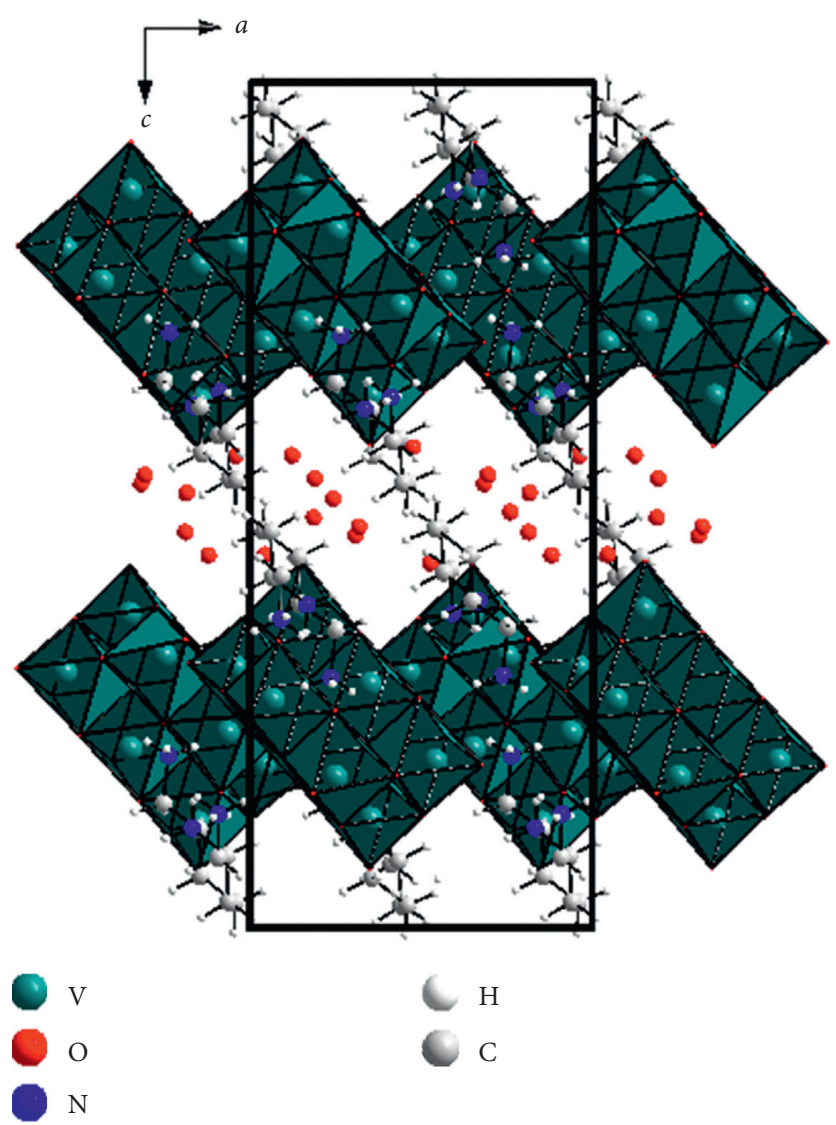

Figure 3: Projection of the $\left(\mathrm{C}_{7} \mathrm{~N}_{3} \mathrm{H}_{20}\right)_{2} \mathrm{~V}_{10} \mathrm{O}_{28} \cdot 4.21 \mathrm{H}_{2} \mathrm{O}$ structure along the [010] direction.

TABLE 3: Hydrogen bonds in $\left(\mathrm{C}_{7} \mathrm{~N}_{3} \mathrm{H}_{20}\right)_{2} \mathrm{~V}_{10} \mathrm{O}_{28} \cdot 4.21 \mathrm{H}_{2} \mathrm{O}$ compound.

\begin{tabular}{|c|c|c|c|c|}
\hline D-H...A & D-H $(\AA)$ & H...A $(\AA)$ & D...A $(\AA)$ & D-H...A $\left({ }^{\circ}\right)$ \\
\hline N11-H11A...O14 & 0.890 & 2.437 & 2.933 & 115.57 \\
\hline $\mathrm{N} 11-\mathrm{H} 11 \mathrm{~A} \ldots \mathrm{O} 27^{\mathrm{ii}}$ & 0.890 & 2.271 & 3.075 & 150.21 \\
\hline N11-H11B. .OO4 & 0.890 & 2.431 & 2.942 & 116.83 \\
\hline N11-H11B. .O26 ${ }^{\mathrm{i}}$ & 0.890 & 2.502 & 3.355 & 160.88 \\
\hline $\mathrm{N} 11-\mathrm{H} 11 \mathrm{C} \ldots \mathrm{O} 22^{\mathrm{ii}}$ & 0.890 & 2.253 & 2.846 & 123.85 \\
\hline N13-H13A...OW1 $1^{\text {iii }}$ & 0.890 & 2.371 & 3.091 & 138.08 \\
\hline N13-H13B...O9 ${ }^{\mathrm{ii}}$ & 0.890 & 2.055 & 2.925 & 165.13 \\
\hline N13-H13C. .O13 & 0.890 & 2.095 & 2.917 & 153.19 \\
\hline N13-H13C. .O25 & 0.890 & 2.564 & 3.248 & 134.17 \\
\hline C11-H11E. .O $6^{\mathrm{i}}$ & 0.970 & 2.619 & 3.508 & 152.36 \\
\hline N21-H21A...O15 & 0.890 & 2.403 & 2.899 & 149.63 \\
\hline N21-H21A...O26 & 0.890 & 2.289 & 3.090 & 164.32 \\
\hline N21-H21B...O19 & 0.890 & 2.229 & 2.828 & 124.34 \\
\hline $\mathrm{N} 21-\mathrm{H} 21 \mathrm{C} . \mathrm{O}^{\mathrm{ii}}$ & 0.890 & 2.412 & 2.934 & 117.73 \\
\hline $\mathrm{N} 21-\mathrm{H} 21 \mathrm{C} . . \mathrm{O} 27^{\mathrm{i}}$ & 0.890 & 2.427 & 3.282 & 161.14 \\
\hline $\mathrm{N} 23-\mathrm{H} 23 \mathrm{~A} \ldots \mathrm{O} 18^{\mathrm{i}}$ & 0.890 & 2.490 & 3.232 & 141.20 \\
\hline $\mathrm{N} 23-\mathrm{H} 23 \mathrm{~A} \ldots \mathrm{O} 25^{\mathrm{i}}$ & 0.890 & 2.584 & 3.199 & 126.99 \\
\hline N23-H23A...OW6 & 0.890 & 2.636 & 3.304 & 132.60 \\
\hline $\mathrm{N} 23-\mathrm{H} 23 \mathrm{~B} \ldots \mathrm{O} 16^{\mathrm{ii}}$ & 0.890 & 2.125 & 2.916 & 147.53 \\
\hline $\mathrm{N} 23-\mathrm{H} 23 \mathrm{~B} \ldots \mathrm{O} 28^{\mathrm{ii}}$ & 0.890 & 2.445 & 3.164 & 138.15 \\
\hline N23-H23C. .O12 & 0.890 & 2.077 & 2.938 & 162.55 \\
\hline
\end{tabular}

Symmetry codes are (i) $-x+1, y+1 / 2,-z+3 / 2$, (ii) $x-1, y$, z, and (iii) $x, y-1, z$. 


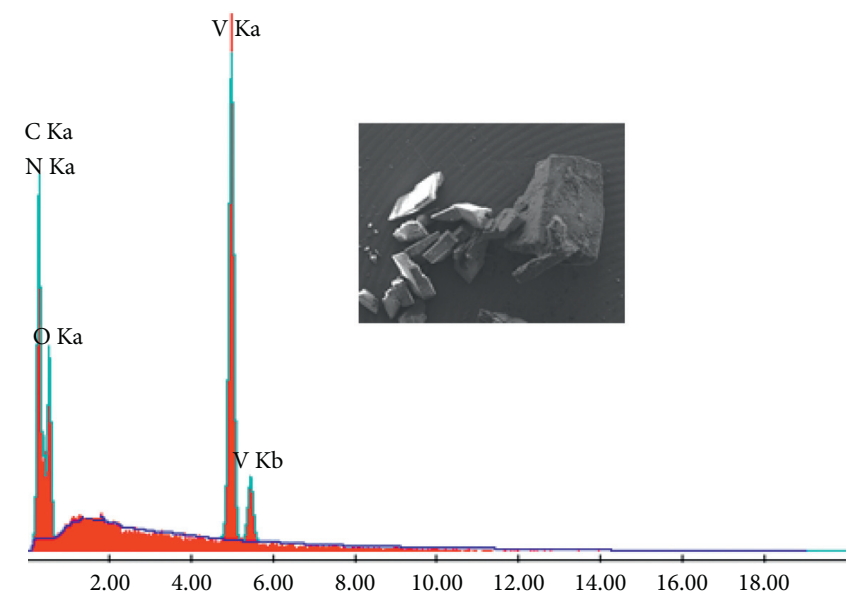

Figure 4: SEM-EDX of the $\left(\mathrm{C}_{7} \mathrm{~N}_{3} \mathrm{H}_{20}\right)_{2} \mathrm{~V}_{10} \mathrm{O}_{28} \cdot 4.21 \mathrm{H}_{2} \mathrm{O}$ compound.

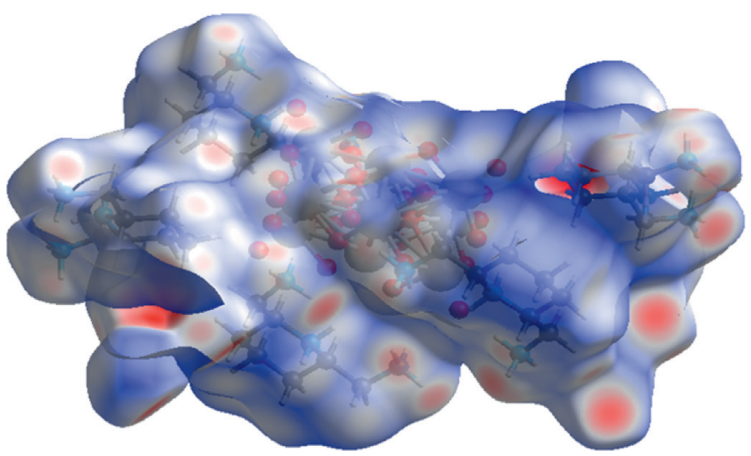

FIgURE 5: Hirshfeld surface mapped over $d_{\text {norm }}$ of the $\left(\mathrm{C}_{7} \mathrm{~N}_{3} \mathrm{H}_{20}\right)_{2} \mathrm{~V}_{10} \mathrm{O}_{28} \cdot 4.21 \mathrm{H}_{2} \mathrm{O}$ compound.

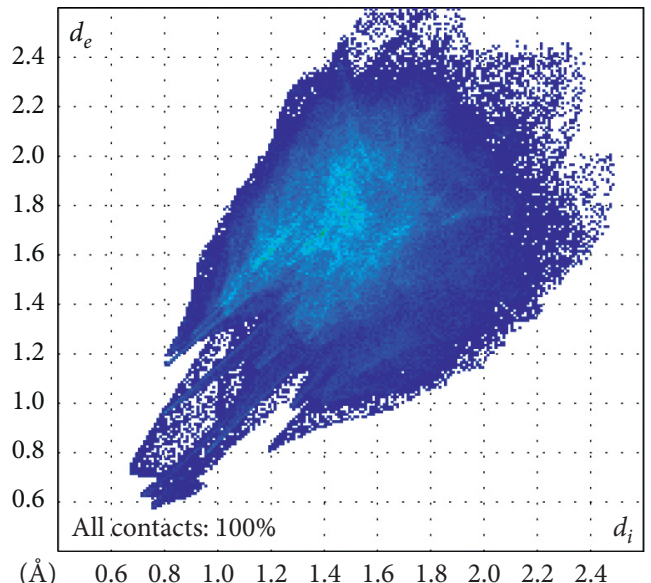

(a)

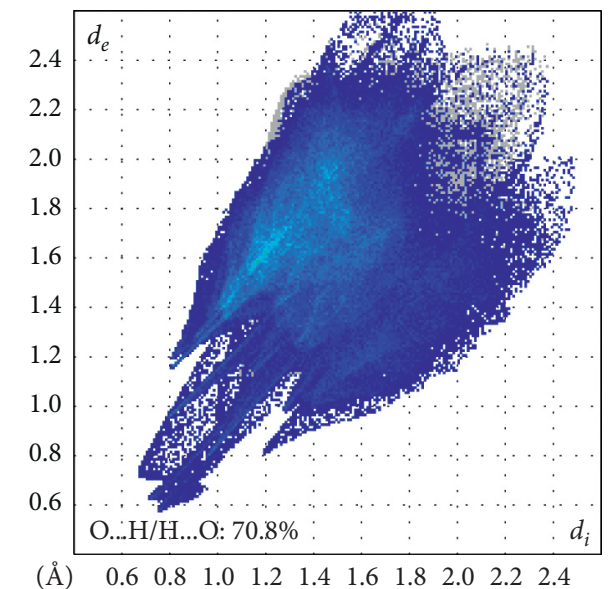

(b)

Figure 6: Continued. 


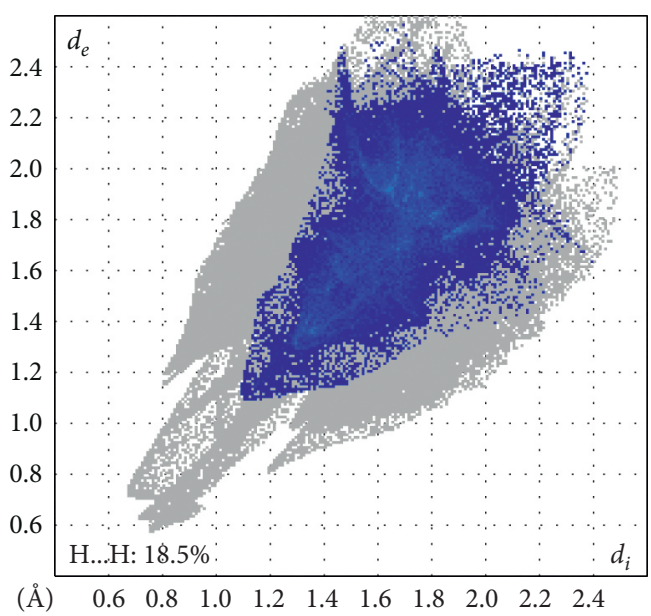

(c)

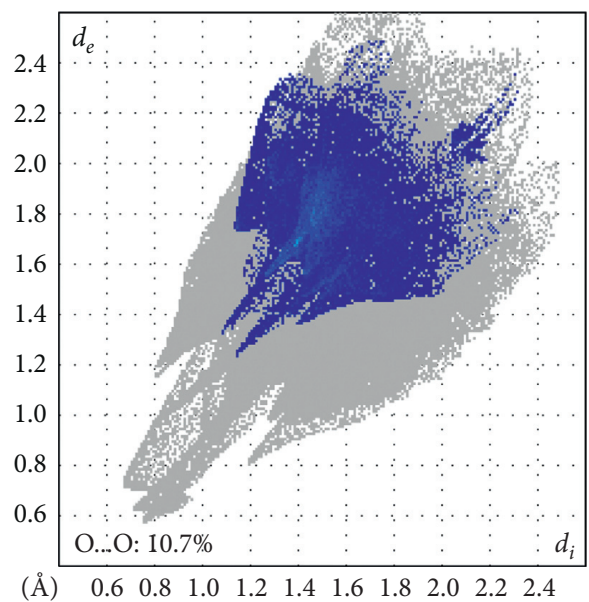

(d)

FIGURE 6: 2D fingerprint plots of the studied compound resolved into all contacts (a) and O...H/H... (b), H...H (c), and O...O (d) contacts.

from 3.092(1) to 3.121(2) ̊. These distances are consistent with those found in the compounds studied in the bibliography $[23,24]$.

The projection of the structure along the [100] direction shows that the decavanadate groups and organic cations form a three-dimensional framework that leaves free tunnels in which the water molecules are lodged (Figure 2).

The distortion indexes of $\mathrm{VO}_{6}$ octahedra ranged between $8.1 \%$ and $16.7 \%$ [11] (Table 2). The vanadium is in the +5 oxidation state. This result was confirmed by the bond valence sum calculations (Table 2) according to Brown [25] $\left(S=\sum \mathrm{si}=\sum \exp \left[\left(R_{0}-R_{i}\right) / B\right]\right)$.

The structure of $\left(\mathrm{C}_{7} \mathrm{~N}_{3} \mathrm{H}_{20}\right)_{2} \mathrm{~V}_{10} \mathrm{O}_{28} \cdot 4.21 \mathrm{H}_{2} \mathrm{O}$ compound can be described as a layered structure parallel to the (001) plane (Figure 3).

Organic cations are linked only by van der Waals interactions. The cohesion of the structure is ensured by hydrogen bonds, van der Waals interactions, and N-H...O and $\mathrm{O}-\mathrm{H} . . . \mathrm{O}$ hydrogen bonds.

In this structure, the hydrogen bonds are weak with the D-A bond lengths varying from 2.846 to $3.508 \AA$ according to Brown [26] (Table 3). Mean values of distances C-C and C-N are, respectively, 1.512(2) and 1.509(2) A. These bond lengths are in agreement with those reported in the literature $[27,28]$.

3.2. IR Spectroscopic Characterisation. The swept frequency range of the IR spectrum extends from 4000 to $500 \mathrm{~cm}^{-1}$ (Figure SI. 1). The bands at 825, 750, 676, 600, 546, and $398 \mathrm{~cm}^{-1}$ are assigned to the internal vibration modes of the $\mathrm{VO}_{6}$ octahedra [14]. The strong band at $966 \mathrm{~cm}^{-1}$ is assigned to the vibration modes $v(\mathrm{~V}=\mathrm{O})$. The broad band located in the $2800-3430 \mathrm{~cm}^{-1}$ domain is attributed to $-\mathrm{OH}$ groups involved in hydrogen bonds [29]. The vibration modes $v(\mathrm{C}-\mathrm{H}), v(\mathrm{C}-\mathrm{N}), v(\mathrm{C}-\mathrm{C})$, and $v(\mathrm{~N}-\mathrm{H})$ are located around 1164, 1199, 1384, 1487, 1624, 1940, and $2098 \mathrm{~cm}^{-1}$ [30].
3.3. SEM-EDX Analysis. The scanning electron microscopy of single crystals of $\left(\mathrm{C}_{7} \mathrm{~N}_{3} \mathrm{H}_{20}\right)_{2} \mathrm{~V}_{10} \mathrm{O}_{28} \cdot 4.21 \mathrm{H}_{2} \mathrm{O}$ phase revealed the presence of vanadium $(\mathrm{V})$, nitrogen $(\mathrm{N})$, carbon $(\mathrm{C})$, and oxygen $(\mathrm{O})$ in the sample studied. The morphology of crystals and the spectrum obtained are presented in Figure 4.

3.4. Hirshfeld Surface Analysis. The Hirshfeld surfaces of $\left(\mathrm{C}_{7} \mathrm{~N}_{3} \mathrm{H}_{20}\right)_{2} \mathrm{~V}_{10} \mathrm{O}_{28} \cdot 4.21 \mathrm{H}_{2} \mathrm{O}$, over a $d_{\text {norm }}$, are shown in Figure 5. In the crystal, molecules are linked into a threedimensional network by $\mathrm{N}-\mathrm{H}$. . .O and O-H. . .O hydrogen bonds. In order to visualize the intermolecular interactions in the crystal of the title compound, the Hirshfeld surface (HS) analysis was carried out by using Crystal Explorer. Figure 5 shows the presence of $\mathrm{O}-\mathrm{H}$... $\mathrm{O}$ and $\mathrm{N}-\mathrm{H}$...O bonds and $\mathrm{H}$...H interactions.

The total contacts are given in Figure 6(a). The structure is dominated by $\mathrm{O} \ldots \mathrm{H} / \mathrm{H} \ldots \mathrm{O}(70.8 \%)$ (Figure 6(b)) and H...H (18.5\%) (Figure 6(c)) contacts. The O...O-type interactions represent 10.7\% (Figure 6(d)).

\section{Conclusion}

A novel organic-inorganic framework of $\left(\mathrm{C}_{7} \mathrm{~N}_{3} \mathrm{H}_{20}\right)_{2} \mathrm{~V}_{10} \mathrm{O}_{28} \cdot 4.21 \mathrm{H}_{2} \mathrm{O}$ has been successfully synthesized by evaporation of an aqueous solution at room temperature. Its single structure was determined using singlecrystal X-ray diffraction, and it was characterized by FTIR and SEM analysis. The structure of the obtained compound is formed by the decavanadate groups and the organic cations. It can be described as a three-dimensional framework that contains tunnels in which the water molecules are located. The crystal structure was stabilized by O-H. . . and $\mathrm{N}-\mathrm{H}$. . .O hydrogen bonds. The Hirshfeld surface analysis reveals that O...H/H. .O (70.8\%) and H...H (18.5\%) intermolecular interactions are the most dominant in the crystal structure. In this perspective, we plan to perform 
further characterizations to explore the anticancer activity and therapeutic intervention of the title compound.

\section{Data Availability}

The CIF file containing complete information about the structure of the obtained structure was deposited with the Cambridge Crystallographic Data Center (CCDC no.1968413). The file is freely available upon request from the following web site: http://www.ccdc.cam.ac.uk/data_request/cif.

\section{Conflicts of Interest}

The authors declare no conflicts of interest.

\section{Acknowledgments}

This work was supported by a national federated project research under the code PRF2019-D3P2, granted by the Tunisian Ministry of Higher Education and Scientific Research. The authors sincerely thank Ksiksi Abd El-Hakim, for support in editing the article.

\section{Supplementary Materials}

Figure SI: infrared spectrum of the $\left(\mathrm{C}_{7} \mathrm{~N}_{3} \mathrm{H}_{20}\right)_{2} \mathrm{~V}_{10} \mathrm{O}_{28} \cdot 4.21 \mathrm{H}_{2} \mathrm{O}$ compound. (Supplementary Materials)

\section{References}

[1] A. A. Ksenofontov, M. M. Lukanov, N. G. Bichan et al., "Noncovalent supramolecular systems with photoinduced electron transfer based on zinc bis(dipyrromethenate)s and $\mathrm{C}_{60}$," Dyes and Pigments, vol. 185, Article ID 108918, 2021.

[2] S. K. Seth, P. Manna, N. J. Singh et al., "Molecular architecture using novel types of non-covalent $\pi$-interactions involving aromatic neutrals, aromatic cations and $\pi$-anions," CrystEngComm, vol. 15, no. 7, 1285 pages, 2013.

[3] J. Zhou, J. Hu, M. Li et al., "Hydrogen bonding directed coassembly of polyoxometalates and polymers to core-shell nanoparticles," Materials Chemistry Frontiers, vol. 2, no. 11, pp. 2070-2075, 2018.

[4] Y. Wang and I. A. Weinstock, "Cation mediated self-assembly of inorganic cluster anion building blocks," Dalton Transactions, vol. 39, no. 27, 6143 pages, 2010.

[5] J.-M. Brégeault, M. Vennat, L. Laurent Salles et al., "From polyoxometalates to polyoxoperoxometalates and back again; potential applications," Journal of Molecular Catalysis A: Chemical, vol. 250, no. 1-2, pp. 177-189, 2006.

[6] R. ksiksi, Z. abdelkafi-koubaa, S. Mlayah-Bellalouna et al., "Synthesis, structural characterization and antitumoral activity of $\left(\mathrm{NH}_{4}\right)_{4} \mathrm{Li}_{2} \mathrm{~V}_{10} \mathrm{O}_{28} \cdot 10 \mathrm{H}_{2} \mathrm{O}$ compound," Journal of Molecular Structure, vol. 1229, Article ID 129492, 2021.

[7] Q. Liu, P. He, H. Yu et al., "Single molecule-mediated assembly of polyoxometalate single-cluster rings and their three-dimensional superstructures," Science Advances, vol. 5, no. 1, pp. 1-10, 2019.

[8] N. Ayoub, A. D. Jeyasekharan, J. A. Bernal, and A. R. Venkitaraman, "HP1- $\beta$ mobilization promotes chromatin changes that initiate the DNA damage response," Nature, vol. 453, no. 7195, pp. 682-686, 2008.
[9] M. Aureliano and R. M. C. Gândara, "Decavanadate effects in biological systems," Journal of Inorganic Biochemistry, vol. 99, no. 5, pp. 979-985, 2005.

[10] T. Yamase, "Anti-tumor, -viral, and -bacterial activities of polyoxometalates for realizing an inorganic drug," Journal of Materials Chemistry, vol. 15, no. 45, 4773 pages, 2005.

[11] M. Paula, M. Marques, D. Gianolio et al., "An exafs approach to the study of polyoxometalate-protein interactions: the case of decavanadate-actin," Inorganic Chemistry, vol. 56, no. 18, pp. 10893-10903, 2017.

[12] R. Prudent, V. Moucadel, B. Laudet et al., "Identification of polyoxometalates as nanomolar noncompetitive inhibitors of protein kinase CK2," Chemistry \& Biology, vol. 15, no. 7, pp. 683-692, 2008.

[13] T. Aissa, R. Ksiksi, R. Doghri, N. S. Abid, and M. F. Zid, "Synthesis of a new vanadium complex (V), hexa [4-methylimidazolium] decavanadate trihydrate $\left(\mathrm{C}_{4} \mathrm{H}_{7} \mathrm{~N}_{2}\right)_{6} \mathrm{~V}_{10} \mathrm{O}_{28} \cdot 3 \mathrm{H}_{2} \mathrm{O}$ : physico-chemical and biological characterizations," Journal of Molecular Structure, vol. 1236, Article ID 130331, 2021.

[14] M. Louati, R. Ksiksi, I. E. Dhouib et al., "Synthesis, structure and characterization of a novel decavanadate, $\mathrm{Mg}\left(\mathrm{H}_{2} \mathrm{O}\right)$ $6\left(\mathrm{C}_{4} \mathrm{~N}_{2} \mathrm{H}_{7}\right)_{4} \mathrm{~V}_{10} \mathrm{O}_{28} \cdot 4 \mathrm{H}_{2} \mathrm{O}$, with a potential antitumor activity," Journal of Molecular Structure, vol. 1242, Article ID 130711, 2021.

[15] K. Harms and S. Wocadlo, XCAD4, University of Marburg, Marburg, Germany, 1995.

[16] L. J. Farrugia, "WinGXandORTEP for windows: an update," Journal of Applied Crystallography, vol. 45, no. 4, pp. 849-854, 2012.

[17] G. M. Sheldrick, "A short history of SHELX," Acta Crystallographica Section A Foundations of Crystallography, vol. 64, no. 1, pp. 112-122, 2008.

[18] G. M. Sheldrick, "Crystal structure refinement withSHELXL," Acta Crystallographica Section C Structural Chemistry, vol. 71, no. 1, pp. 3-8, 2015.

[19] A. C. T. North, D. C. Phillips, and F. S. Mathews, "A semiempirical method of absorption correction," Acta Crystallographica Section A, vol. 24, no. 3, pp. 351-359, 1968.

[20] K. Brandenburg, Diamond, Crystal Impact GbR, Bonn, Germany, 2001.

[21] S. K. Wolff, D. J. Greenwood, J. J. McKinnon, D. Jayatilaka, and M. A. Spackman, Crystal Explorer 3.1, University of Western Australia, Perth, Australia, 2012.

[22] A. Parkin, G. Barr, A. Collins et al., "Using cluster analysis to study transition-metal geometries: four-coordinate complexes with two salicylaldiminato or related ligands," Acta Crystallographica Section B Structural Science, vol. 63, no. 4, pp. 612-620, 2007.

[23] F. P. A. Fabbiani, L. T. Byrne, J. J. McKinnon, and M. A. Spackman, "Solvent inclusion in the structural voids of form II carbamazepine: single-crystal X-ray diffraction, NMR spectroscopy and Hirshfeld surface analysis," CrystEngComm, vol. 9, no. 9, 728 pages, 2007.

[24] R. Ksiksi, M. Graia, A. Driss, and T. Jouini, “Décavanadate sel double de dilithium et tétraammonium décahydrate, $\left(\mathrm{NH}_{4}\right)_{4} \mathrm{Li}_{2}\left[\mathrm{~V}_{10} \mathrm{O}_{28}\right] \cdot 10 \mathrm{H}_{2} \mathrm{O}$," Acta Crystallographica Section E Structure Reports Online, vol. 60, no. 8, pp. i105-i107, 2004.

[25] I. D. Brown, "Chemical and steric constraints in inorganic solids," Acta Crystallographica Section B Structural Science, vol. 48, no. 5, pp. 553-572, 1992.

[26] I. D. Brown, "On the geometry of O-H.O hydrogen bonds," Acta Crystallographica Section A, vol. 32, no. 1, pp. 24-31, 1976. 
[27] Z. A. Siddiqi, Anjuli, P. K. Sharma et al., "Novel decavanadate cluster complexes $\left[\mathrm{H}_{2} \mathrm{~V}_{10} \mathrm{O}_{28}\right][\mathrm{LH}]_{4} \cdot \mathrm{nH}_{2} \mathrm{O} \quad(\mathrm{L}=$ Imidazole, $n=2$ or 2-methylimidazole, $n=0)$ : preparation, characterization and genotoxic studies," Journal of Molecular Structure, vol. 1029, pp. 86-91, 2012.

[28] J. Yan, H. Zhao, Z. Li et al., "A self-assembled 3D hydrogen bonded network constructed from polyoxovanadate and protonated organic substrate with a solvent hydrolysis reaction," Journal of Cluster Science, vol. 20, no. 4, pp. 717-724, 2009.

[29] L. R. Guilherme, A. C. Massabni, A. C. Dametto, R. de Souza Corrêa, and A. S. de Araujo, "Synthesis, infrared spectroscopy and crystal structure determination of a new decavanadate," Journal of Chemical Crystallography, vol. 40, no. 11, pp. 897-901, 2010.

[30] I. Omri, T. Mhiri, and M. Graia, "Novel decavanadate cluster complex $(\mathrm{HImz})_{12}\left(\mathrm{~V}_{10} \mathrm{O}_{28}\right) 2 \cdot 3 \mathrm{H}_{2} \mathrm{O}$ : synthesis, characterization, crystal structure, optical and thermal properties," Journal of Molecular Structure, vol. 1098, pp. 324-331, 2015. 